\title{
Development of corporate associations of construction industrial enterprises and subjects of financial and credit environment by financial infrastructure merging
}

\author{
Ramil Mavlioutov ${ }^{1, *}$, Ekaterina Butenko ${ }^{1}$, and Regina Menyailova ${ }^{1}$ \\ ${ }^{1}$ Volgograd State Technical University, 400067 Volgograd, Russian Federation
}

\begin{abstract}
The article is devoted to solving important problems of the modern economy, which is the formation, development, and improvement of the efficiency of the combined corporate structures, including industrial enterprises of the construction industry, development directions and mechanisms of regulation of the process of interaction with the financial and credit environment, as well as the formation of corporations, financial infrastructure. According to the authors, it is the basis for the successful development of the industry.
\end{abstract}

An active role in the financial and credit support of industrial enterprises play a variety of financial institutions, especially commercial banks. Industrial enterprises and commercial banks are able to independently generate and conduct their own financial policies. Development of ways and forms of interaction economical industrial enterprise with the bank is among the most important tasks of strategic planning at the enterprise.

Economic relations is first of all, the enterprise the process of interaction with the various economic actors, including with financial and credit environment, in terms of location and construction of the most effective economic interactions [1-3]. This process is quite complex because of the different approach of economic actors in the process of formation and profit on the basis of its production activities.

Building a system of effective interaction with the elements of the environment is an important area of activity for the industrial enterprises, which allows not only effectively respond to changes in environmental conditions, but also to actively use the resources of the environment to enhance and improve its efficiency [4, 5].

The joint economic planning process should be defined [6]:

a system of interrelated objectives, taking into account their priority;

tasks that will have to decide on the various stages of preparation and implementation of banking products;

the mechanisms and methods of achieving these goals.

You must have at their disposal a reliable and sufficient information on the state of the financial and economic environment, the situation in the servicing banks. Primarily need information about the bank's management, its financial position and reputation.
The shares in the stock market and a loan at the bank are the main type of financial activity of the industrial enterprises of the construction industry.

Imperfection of the existing system and the mechanism of interaction of "industrial undertaking - the bank" in the conditions of transitive economy dictates the more radical forms of organizational and economic interaction of industrial enterprises with the bank in the direction of creating integrated (combined) corporate type structures to work on the final result in a single financial and technological chain [7-10]. The main advantages of large integrated corporate structures include: the lack of restrictions on the areas of activity, reducing business risks, the ability to attract an unlimited number of investors and the accumulation of significant amounts of capital, high capacity handling.

Development of modern integrated corporate structures are characterized by the increasing complexity of their internal financial and organizational structure, the expansion of economic ties, increasing the need for additional financial resources, the continuing concentration of capital, the increasing complexity of financial relations in the globalization process [11]. As noted earlier, a major role in the structure of modern integrated corporate structures play financial institutions: banks, insurance and investment companies, the purpose of the formation and activity of which is to ensure financial stability and development corporations.

The significance of combined (integrated) corporate structures in industrial production, their active development associated with the accumulation and concentration of capital and the increasing complexity of structures require adequate scientific analysis of these processes, the timely identification and resolution of problems of formation, regulation and improve the effectiveness of their activities.

\footnotetext{
Corresponding author: ramil-2002@mail.ru
} 
In the scientific literature [12-14] to determine the integrated corporate structures (associations) uses the term "corporation", "financial-industrial group", "holding", "complex economic systems", "Industrial and Financial Systems," "complex integrated structures" and others. The most commonly to refer to the combined corporate entities, the term "financial-industrial group". In general, financial and industrial group is the integration of banking and industrial capital and is treated as an association of legally independent parties fully or partially pooling their assets with a view to economic integration. Another term often used to determine the association, is the term "corporation", which, in this case, does not accurately describe the name of the association of legal entities, as it has a wider meaning and is used to characterize the company. The unique characteristics of the term "corporation" in the Russian economic and legal theory and practice is not, so when you use it is necessary to clarify some of the corporations in question is a corporation - a joint-stock company or corporation, which is a group of companies [15].

Formation and development of financial and industrial corporate associations determines the prevailing trends and prospects of the current process of corporate development:

strengthening the process of concentration of capital; widespread associations conglomerate type;

the development of processes to optimize the asset structure in conglomerates;

globalization of economic growth;

increasing competition between corporations in different sectors of the market;

the emergence and development of new forms of integration;

growth in the number and volume of mergers and acquisitions;

an increase in the role of banks and other financial institutions in the creation and management of corporate entities.

As the external environment in relation to the combined corporate structures, the financial and credit system, the main elements of which are banks, insurance companies, pension and investment funds, is a financial infrastructure that enables corporations to attract the necessary financial resources and allocate temporarily free funds, which makes it possible effectively manage the size and structure of the association.

It was revealed that the considered approaches to the analysis of relations between the combined corporate structures and financial systems, are valid only if the structure of the corporate association lacking the financial and credit institutions. The situation changes when a part of the corporate association incorporated financial institutions. In this case, the two blocks are formed within the corporation: production (production and sales) and financial. Production unit, whose main task is the management of production and marketing of products consisting of industrial, commercial and other non-financial institutions [16, 17]. Financial unit includes a variety of financial and credit institutions: banks, insurance companies, investment and pension funds and other financial institutions, its task is to manage the financial corporation engaging and accumulation of financial assets.

With significant amounts of financial resources and implementing large-scale industrial activity, the corporation ceases to be a recipient of financial services, its demand for basic financial services can be satisfied with the help of its member financial institutions. In this case the financial and credit institutions of corporate associations are both part of the corporate structure and part of the financial system. This approach allows us to allocate the financial infrastructure of the composition of the external and internal components, which can be defined as: foreign financial infrastructure and domestic financial infrastructure. At the same time as the domestic financial infrastructure, understood as a set of financial and credit institutions that are part of the corporate associations, and acting in the interests of the association [18].

Financial institutions that make up the external financial infrastructure, act in their own interests, while the financial institutions that are part of the domestic financial infrastructure, acting in the interests of corporate associations. At the same time corporations are interested in the inclusion of financial institutions in its structure, as a result, they gain access to additional resources and opportunities, and provide their priority position in the competition. In the course of its activities and financial-credit organizations representing domestic financial infrastructure, have the opportunity to combine various financial functions, the main of which are: the centralization and redistribution of resources, internal corporate lending, management of internal corporate cash flows, joint activity in the stock market in the interests of association, co-insurance of risks and other functions.

At the same time, coming into a body corporate, industrial and financial organizations have different goals. Manufacturing enterprises in the merger is expected to receive additional financial resources needed for the modernization and development of production. Finance companies require to be able to more efficiently and with less risk to use available capital, to achieve a higher level of control over the invested capital to be able to monitor and control the corporation [19].

The complexity and diversity of the financial and economic relations in the economy contributed to a large number of different types of integrated corporate structures. Depending on the purpose of cooperation, degree of independence and the nature of economic relations between the parties, evolved a variety of options combining industry with financial and credit environment. Depending on the prevailing conditions and opportunities for association members to realize their objectives, the various forms of relationships established between them [19]:

financial and credit institutions provide financial services to isolated and do not have a significant impact on corporate activities of the association;

financial and credit institutions, providing comprehensive financial services and participate in the 
activities of corporate association, not being members of the association;

financial and credit institutions, are part of the corporate association, but their activities are limited and dependent nature of the provision of financial services;

financial and credit organizations are part of the corporate associations, and monitor its activities;

financial and credit organizations, manage the activities of the corporate association.

The first two forms of relationships correspond to relationships with external financial corporations infrastructure. The other three forms relate to the domestic financial infrastructure and relationships defined within the corporation [20]. Financial institutions that have these types of relationships are part of the corporate association, and can become a financial and management center under certain conditions.

The basis of the domestic financial infrastructure such corporate associations make up the banks, which often act as initiators of the establishment and other financial institutions: insurance companies, investment and pension funds, venture capital funds, brokerage firms.

The inclusion of financial companies in the corporation leads to the formation of the domestic financial infrastructure, which allows, due to the concentration of financial resources to carry out the structural development of even more rapidly.

The core of the domestic financial infrastructure includes banks that have the ability to concentrate large volumes of financial resources and ensure effective management. Other financial institutions that are part of the corporation, acting together with the bank and usually under its control. The Bank created a body corporate or incorporated into its structure, aims, and after a certain period of time becomes the center of the corporation. In the same way and the banks are not included in the corporation. While external financial infrastructure, they seek to capture or form their own body corporate, becoming thus its center (the parent organization) [21].

Consider a situation where a bank included in the corporate association, but its activity is dependent and limited to the provision of financial services. Educated commercial banks and industrial enterprises complex system aims of its existence, as well as any commercial entity maximizing the economic effect of their activities. The economic effect of the complex functioning of the system $\left(E E_{s c}\right)$ is the amount of the economic benefit of the enterprise operation $\left(E E_{i e}\right)$ and economic impact of the bank operation $\left(E E_{b}\right)$ :

$$
E E_{s c}=E E_{i e}+E E_{b}
$$

The economic effect of the enterprise from product sales is maximal $\left(E E_{\text {ie } \max }\right)$ for a certain amount of sales $\left(Q_{\max }\right)$. Its increase can be achieved through the use of modern financial instruments: promissory note loans reduces costs and factoring leads to an increase in sales by accelerating the turnover of handling funds.

Consider the mechanism of the economic effect of the bank - the second part of the reporting system of the complex. The economic effect in general terms can be calculated as the difference between revenues and costs.
The economic effects of the company and the bank, has a maximum point, which correspond to certain parameters now attracting / bank providing financial resources, allowing to obtain the greatest economic benefit of the complex functioning of the system. The dependence of the income and expenses of a particular industrial plant construction industry LSC Sebryakovcement. LSC Sebryakovcement is a Soviet and subsequently Russian company the cement industry. It is located in the city of Mikhailovka of the Volgograd region. Optimum (in this case a maximum of) its economic effect from realization of production is reached at $14627 \mathrm{t}$ and is $1,305 * 10^{8}$ rubles.

However, to achieve it, the company needs to attract credit resources of the bank and shall be paid for the use of borrowed funds is the reward of his income.

To go from an absolute return performance relative to the manufacturing facility will take the duration of operating cycle of 90 days.

The economic effect of the production activity of the enterprise has an extreme (in this case the maximum), which corresponds to $16.9 \%$ of annual profitability.

By combining in one figure charts of income and expenses of the bank, get a graphical interpretation. Highs economic benefit obtained by the bank from interacting with businesses, are achieved for different curves for different sizes of bank fees levied:

Maximum income of the bank reached at a rate of $25.3 \%$ per annum and is $2.17 * 10^{9}$ rubles;

the maximum cost of the bank when the rate reached $26.4 \%$ and is $1.28 * 10^{9}$ rubles;

maximum economic effect is achieved by the bank at a rate of $22 \%$ per annum and is $9.05^{*} 10^{8}$ rubles.

The extremum is achieved when the yield of $18 \%$ per annum, while the value of the economic benefit of the complex (added value in the supply chain) is $2.2 \mathrm{bln}$. rubles.

Another example of inter-system interaction can be a bunch of Real Estate Investment Trust (REIT) with the industrial construction industry. REIT operate in the legal system of the United States since the 1960s [22],

The implementation of the construction project for the construction with the use of REIT can be represented as follows (fig. 1):

a step of forming REIT. Accumulation of assets (cash, land or rights of their lease, design and estimate documentation);

finally, the management company with the companydeveloper of the investment agreement, the subject of which is the construction of facilities on land that is part of a structure of the REIT assets;

transfer of property rights under the treaty obligations of the REIT assets;

trust transfer of the developer of design and estimate documentation,

company-builder obtaining a building permit;

implementation of construction and installation work for the company-developer of the funds received as funding under the investment agreement.

obtain company-builder permit for commissioning of constructed object;

the transfer of the object of the REIT assets. 


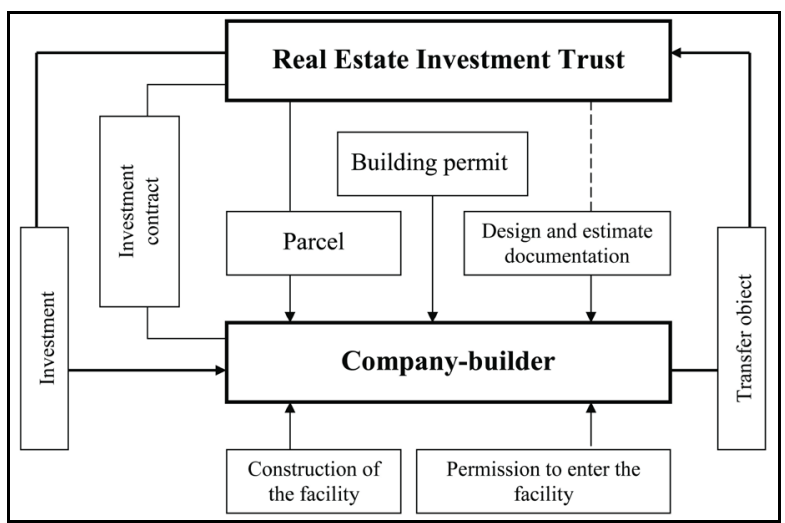

Fig. 1. Implementation of the construction project with the participation of Real Estate Investment Trust.

Industrial construction industry serves as a companybuilder. REIT has the potential active participant in the construction market. With the possible direct investment trust for real estate construction projects.

In the Russian legal system analogous to the REIT is a unit investment fund of real estate. This kind of financial structure have been operating for 15 years. As of 2016, the number of unit investment funds of real estate exceeding 500.

The decision of important problems of the modern economy - the formation, development and improvement of the efficiency of the combined corporate structures, including industrial enterprises with a long production cycle, development directions and control the process of interaction mechanisms in the financial and credit environment, as well as the formation of corporations, financial infrastructure, in our opinion, is the basis for successful development of industrial production at the present stage of development.

Intersystem interactions between industrial enterprises and banks have both integrative and disintegrative character. This is due on the one hand the impossibility of the existence of each system separately from the other, and on the other, a conflict of interest between the cooperating parties.

In the system the interaction of industrial enterprise with a bank to obtain additional economic benefit one side automatically leads to the formation of a negative economic effect on the opposite side. This kind of operation is not aimed at the optimization of the interaction between the real and financial sectors, and in the solution of internal problems. For example, reduce the cost of the passage of payments, increased control over transactions produced, obtaining the mechanism of tax optimization and additional sources of financing.

In conclusion, we note that the individual is very important from a practical point of view, are conflictfree distribution of tasks resulting economic effect between the participants of the complex and the construction of intersystem organizational cash flow management services

\section{References}

1. L. Cai, J. Cui, H. Jo, Journal of Business Ethics, 139, 3, 563-594 (2016)

2. B.N. Cline, C.R. Williamson, Journal of Corporate Finance, 41, 572-590 (2016)

3. O.K. Tosun, Financial Management, 45, 4, 953-979 (2016)

4. N. Vafeas, A. Vlittis, Financial Review, 51, 4, 481506 (2016)

5. K.-W. Lee, G.H.-H. Yeo, Review of Quantitative Finance and Accounting, 47, 4, 1221-1250 (2016)

6. B.W. Goh, J. Lee, C.Y. Lim, T. Shevlin, Accounting Review, 91, 6, 1647-1670 (2016)

7. G. Jacoby, J. Li, M. Liu, European Journal of Finance, 1-20 (2016)

8. H. Rim, S.-U. Yang, J. Lee, Journal of Business Research, 69, 9, 3213-3219 (2016)

9. D. Cairns, Accounting in Europe, 12, 2, 187-196 (2015)

10. H. Deangelo, R. Roll, Journal of Finance, 70, 1, 373-418 (2015)

11. X. Chang, S. Dasgupta, Journal of Finance, 64, 1767-1796 (2009)

12. H. DeAngelo, L. DeAngelo, T.M. Whited, Journal of Financial Economics, 99, 235-261 (2009)

13. E. Fischer, R. Heinkel, J. Zechner, Journal of Finance, 44, 19-40 (1989)

14. C.A. Hennessy, T.M. Whited, Journal of Finance, 60, 1129-1165 (2005)

15. B.St. John III, R. Arnett, Journal of Public Relations Research, 26, 2, 103-116 (2014)

16. M. Alzahrani, R.P. Rao, Financial Review, 49, 1, 89-116 (2014)

17. M. Baker, J. Wurgler, Journal of Finance, 57, 1-32 (2002)

18. G. Bittlingmayer, S.M. Moser, Financial Review, 49, 1, 1-19 (2014)

19. A. Pérez, M.M. García de los Salmones, I. Rodríguez del Bosque, European Journal of Marketing, 47, 1, 218-238 (2013)

20. Mignon, A. Rüdinger, Renewable and Sustainable Energy Reviews, 65, 478-488 (2016)

21. Z. Banhalmi-Zakar, Australian Planner, 53, 3, 221231 (2016)

22. Real Estate Investment Trust Act of 1960 